\title{
Is stotteren een spraak-motorische timingstoornis? Een alternatieve geïntegreerde benadering volgens het SAMI-model
}

\author{
Robert van de Vorst $^{1,2}$, Vincent L. Gracco ${ }^{1,2,3}$ \\ ${ }^{1}$ Centre for Research on Brain, Language and Music, Montreal, Canada \\ ${ }^{2}$ School of Communication Sciences and Disorders, McGill University, Montreal, Canada \\ ${ }^{3}$ Haskins Laboratories, New Haven, CT, VS
}

\begin{abstract}
Samenvatting
Stotteren kent vele theorieën die iets trachten te zeggen over de oorzaak en andere verschijnselen verbonden aan de stoornis. Opvallend is dat in Nederland de logopedische praktijk stotteren doorgaans als een "neuromusculaire timingstoornis" duidt en stelt dat de aanleg voor stotteren gerelateerd is aan een mistiming van spraakbewegingen. Naast stotteren als timingstoornis zijn er echter in de loop van de jaren ook andere theorieën geformuleerd. Aangezien de kern van stotteren meestal wordt gezien als een stoornis of verzwakking van spraak-motorische processen zijn in dit artikel specifiek een aantal spraak-motorische modellen besproken. Spraak-motorische theorieën verklaren echter niet altijd de contextuele variabiliteit die vaak gepaard gaat met stotteren; de Speech And Monitoring Interaction (SAMI; Arenas, 2017) hypothese beschouwt naast spraakproductie ook (een verstoorde) monitoring als een belangrijke, mogelijk causale, component van het stotteren. Tot slot is kort belicht welke implicaties de ontwikkeling in theorievorming over stotteren kan hebben voor de klinische praktijk.
\end{abstract}

\begin{abstract}
Summary
Multiple theories aim to explain the cause of stuttering as well as other characteristics related to stuttering. In the Netherlands, speech and language practice usually defines stuttering as a "neuromuscular timing disorder" and states the predisposition to stuttering is confined to mistiming of speech movements. Besides this definition of stuttering as a timing disorder, other theories have been proposed over the years. Since the core of stuttering is usually considered a deficit or limitation of speech-motor processes, several speech-motor models of stuttering are discussed in this paper. These
\end{abstract}

Correspondentieadres: Robert van de Vorst, Centre for Research on Brain, Language and Music, 3640 Rue de la Montagne, Montreal, H3G 2A8, QC, Canada

E-mail: robert .vorst@mail.mcgill.ca 
theories, however, do not always explain the contextual variability that often accompanies stuttering. For example, the Speech And Monitoring Interaction hypothesis (SAMI; Arenas, 2017) considers not only speech production, but also (deficient) monitoring as an important, and perhaps causal, component of stuttering. Finally, this paper highlights how the development of theories about stuttering implicates clinical practice.

\section{Introductie}

Stotteren ${ }^{1}$ is een complexe stoornis met een vooralsnog onbekende oorzaak. Vele theorieën zijn in de loop der jaren naar voren gebracht om zowel de oorzaak als het verdere verloop en specifieke karakteristieken van de stoornis in kaart te brengen. In de laatste drie decennia hebben zowel gedragsstudies, hersenstudies en genetische studies belangrijke bijdragen geleverd aan empirisch onderzoek rondom stotteren die op hun beurt weer theorievorming hebben beïnvloed.

Adequate kennis van de huidige gangbare theorieën en wetenschappelijk verkregen bewijs over stotteren is voor de logopedist(-stottertherapeut) van belang voor een op feiten gebaseerde uitleg aan de cliënt van wat stotteren is, aangezien dit gerelateerd is aan de verwachtingen en mogelijkheden van de therapie. Opvallend is dat in Nederland de logopedische praktijk de kern van het stotteren doorgaans verklaart als een 'timingstoornis'. Soms wordt zelfs specifieker gesproken over een 'neuromusculaire timingstoornis', waarmee wordt bedoeld dat de aansturing (door de hersenen) van de spreekspieren niet optimaal verloopt. De Nederlandse Vereniging voor Stottertherapie (NVST) stelt dat deze component (timingstoornis) de al dan niet genetisch bepaalde aanleg is voor het stotteren. ${ }^{2}$ Ook in de media duiden logopedisten stotteren vaak als een stoornis in de timing van de spraakbewegingen. ${ }^{3}$

In dit artikel willen we illustreren dat in de wetenschap het verklaren van stotteren nog in het stadium van theorievorming is en dat er verschillende - zij het vaak deels overlappende - verklaringen worden gegeven voor het ontstaan en in stand houden van stotteren. Een overzicht van alle theorieën/modellen is buiten de scope van dit artikel. Voor een recent en completer overzicht verwijzen we de geïnteresseerde lezer naar Theoretical Issues in Stuttering (Packman \& Attanasio, 2017). Aangezien de kern van stotteren meestal wordt gezien als een stoornis of verzwakking van spraak-motorische processen (weliswaar onderhevig aan een reeks van andere factoren die van invloed zijn op deze processen) willen we een aantal van deze modellen nader toelichten. We willen belichten dat er tussen deze modellen zowel verschillen als overeenkomsten zijn en dat ze in de huidige vorm nog niet alles over stotteren kunnen verklaren. We willen deze om die reden complementeren met een

\footnotetext{
${ }^{1}$ Tenzij expliciet anders aangegeven wordt met de term 'stotteren' verwezen naar ontwikkelingsstotteren.

${ }^{2}$ Bron: http://www.nedverstottertherapie.nl/wp-content/uploads/2016/07/Toel.werkmodel.volw_.pubers.ouders-1.pdf; http://stotterinterventiecentrum.nl/volwassenen.html

${ }^{3}$ Bron: https://www.nhnieuws.nl/nieuws/213872/Stotteren-op-de-basisschool-Vroeger-gingen-kinderen-mij-weleens-napraten
} 
recent model, Speech And Monitoring Interaction (SAMI; Arenas, 2017), een theorie waarbij spraak/taal productie en cognitieve processen worden geïntegreerd en die mogelijk een verklaring geeft voor het variabele karakter van stotteren. Een uitgebreide bespreking van de bewijslast van iedere theorie of het betogen welke model het meest overeenkomt met wetenschappelijk experimenteel onderzoek is niet het doel van dit artikel; we willen de lezer en de logopedist-(stottertherapeut) ervan bewust maken dat de aanleg van stotteren ogenschijnlijk breder moet worden gezocht dan de veronderstelde timingstoornis en benadrukken dat een sluitend model dat de specifieke verschijnselen en het gevonden experimentele bewijs van stotteren in zijn geheel verenigt vooralsnog ontbreekt. Tot slot zullen we kort bespreken hoe vernieuwende inzichten kunnen worden geïmplementeerd in de klinische praktijk.

\section{Spraak-motorische theorieën en modellen}

In spraak-motorische modellen wordt er vanuit gegaan dat aan stotteren een motorische beperking of stoornis ten grondslag ligt. Er zijn in de loop van de jaren veel varianten van spraak-motorische theorieën beschreven. Voor het gemak zullen we ons hier beperken tot het beschrijven van enkele theorieën en modellen die regelmatig in de wetenschappelijke literatuur over stotteren worden aangehaald. We beginnen met een beknopte bespreking van Charles Van Riper's (1905-1994) theorie van stotteren als (neuromusculaire) timingstoornis, aangezien deze in het Nederlands klinische werkveld nog veelvuldig voorkomt. Vervolgens bespreken we hoe de verbaal-motorische component van stotteren tegenwoordig wordt verklaard vanuit interne modellen, computationele modellen, en een beperking in spraak-motorische vaardigheid (speech motor skill theorie).

\section{Stotteren als neuromusculaire timingstoornis}

Het idee van stotteren als een timing- en/of coördinatiestoornis is al bekend sinds het begin van de twintigste eeuw. In 1928 werd door S. T. Orton (1879-1948) verondersteld dat stotteren werd veroorzaakt door een gebrek aan dominantie van de linkerhersenhelft, hetgeen zou resulteren in een mistiming van spraakbewegingen, ofwel stotteren (Orton, 1928). Later werd de hypothese van een timingstoornis met name door Van Riper voortgezet (Van Riper, 1982) en is sindsdien gangbaar gebleven in zowel de logopedische praktijk als de wetenschap (Etchell, Johnson \& Sowman, 2014). In essentie komt een neuromusculaire timingstoornis er op neer dat bij stotterende personen er in het complexe geheel van de spraakbewegingen iets 'mis' gaat met de timing van de spraakbewegingen: de spieren die verantwoordelijk zijn voor spraak (bijv. tong, lippen, kaak, stembanden, etc.) komen bij personen die stotteren te vroeg dan wel te laat. Stotterend spreken is in feite een reactie op deze mistiming. Het stotteren kan vervolgens worden verergerd door reacties op het stotteren: vechten, vluchten of bevriezen. 


\section{Experimenteel bewijs}

Sinds de publicaties van Van Riper is er veel onderzoek gedaan naar de vraag of er inderdaad sprake is van een verstoring in de timing van de spraakbewegingen bij stotterende personen. Eigenlijk is deze vraag niet echt te beantwoorden aangezien er geen duidelijk criterium wordt gegeven van wat een (on)acceptabele timing zou zijn. Ook is niet duidelijk wat in het spraakproductieproces verkeerd zou moeten timen. Sommige studies laten zien dat stotterende personen van niet-stotterende personen kunnen verschillen in de 'timing' van spraakbewegingen, bijvoorbeeld in de overgang van een consonant naar een klinker: personen die stotteren lijken hierin meer variabel te zijn (Loucks \& De Nil, 2006; Max \& Gracco, 2005). Andere studies tonen een verschil in timing wat betreft spiertractie van spraakbewegingen (van Lieshout, Peters, Starkweather \& Hulstijn, 1993) of zelfs in niet-spraak gerelateerde motoriek (Falk, Müller \& Dalla Bella, 2015; van de Vorst \& Gracco, 2017). Niet alle studies laten echter consequent deze verschillen zien en tonen bovendien dat de individuele variatie en overlap groot kan zijn (van de Vorst, van Vugt \& Gracco, 2018; Walsh \& Smith, 2013). Evenwel zouden de gevonden verschillen in timing kunnen duiden op aanpassingen op het stotteren (Max, Guenther, Gracco, Gosh \& Wallace, 2004).

Hersenstudies hebben deze vraag wederom onder de loep genomen en gekeken naar zowel de timing van activiteit in hersengebieden betrokken bij spraak als ook naar gebieden die meer in het algemeen betrokken zijn bij het timen van (spraak)bewegingen. Hieruit komen bij stotterende personen duidelijke verschillen naar voren ten opzichte van vloeiende sprekers, met name in dieper gelegen breingebieden zoals de basale ganglia (Braun et al., 1997; Chang \& Zhu, 2013; Watkins et al., 2008). Een interessant gegeven is dat deze gebieden direct beter kunnen functioneren met behulp van vloeiendheidsbevorderende condities, zoals bijvoorbeeld het spreken met een metronoom (Toyomura, Fujii \& Kuriki, 2011). Ook op de lange termijn kan er bij volwassen stotterende personen een 'normalisatie' plaatsvinden van met name activiteit in gebieden in de linker hersenhelft die betrokken zijn bij de planning en uitvoering van spraak als ook subcorticale gebieden (e.g., basale ganglia), die onder andere betrokken zijn bij het selecteren en timen van spraakeenheden (Giraud et al., 2008). De uitspraak dat het spraak timings-defect dat ten grondslag zou liggen aan stotteren niet veranderbaar is dient naar onze mening daarom genuanceerd te worden. Een andere mogelijkheid zou kunnen zijn dat de timingstoornis niet zozeer de spreekspieren betreft, maar wellicht een probleem in de interactie tussen de spraak/taalplanning en executie, zoals bijvoorbeeld wordt gesuggereerd door de EXPLAN theorie (Howell \& Au-Yeung, 2002). Ook zou het zo kunnen zijn dat het vooronderstelde timingsprobleem eerder perceptueel dan musculair is. Zo hebben studies laten zien dat stotterende sprekers auditieve informatie temporeel anders kunnen verwerken (Kikuchi et al., 2017; Tahei et al., 2014), al tonen studies dit niet consequent aan (Jansson-Verkaselo et al., 2014). Het lijkt hiermee nog onduidelijk of er sprake is van een timingstoornis in stotteren en zo ja, wat de aard van deze stoornis concreet zou moeten inhouden. 


\section{Stotteren verklaard vanuit interne modellen en sensomotoriek}

Het idee dat mistiming de basis zou vormen voor het stotteren is ook door anderen bekritiseerd. Volgens Max et al. (2004) zou het mogelijk kunnen zijn dat stotterende sprekers de bewegingen correct timen en coördineren, zij het dat ze vaak langzamer worden uitgevoerd (p. 108). Dit laatste kan, zoals beschreven door Max \& Daliri (2018) in deze serie, ook een compenserende motorische strategie weerspiegelen in plaats van een onderliggende oorzaak, een idee dat ook weerklinkt in de speech motor skill theorie (Namasivayam \& Van Lieshout, 2011; van Lieshout, Hulstijn \& Peters, 2004; zie ook 2.4).

Een belangrijke component van het model van stotteren als sensomotorische integratiestoornis is dat mogelijk ook sensorische aspecten (bijvoorbeeld auditieve terugkoppeling) een belangrijke rol kunnen spelen in de ontregeling van spraak-motorische processen bij stotterende personen. Deze theorie baseert zich op een zogenaamd intern model van controle van vrijwillige bewegingen dat ook toepasbaar is op spraakproductie (Max, Guenther, Gracco, Ghosh \& Wallace, 2004). Aangezien in deze serie dit theoretisch model al gedetailleerd aan de orde komt (Max \& Daliri, 2018) zullen we ons hier beperken tot slechts enkele observaties wat betreft het huidige experimentele bewijs.

\section{Experimenteel bewijs}

Zowel in Max et al. (2004) en in Max \& Daliri (2018) worden er vele experimentele studies aangevoerd die het idee van een minder functionerende sensomotorische integratie bij stotteren zonder meer plausibel maken. We willen hier echter twee aspecten duiden die het vooralsnog niet geheel duidelijk maken hoe we deze gegevens precies moeten interpreteren.

Het eerste is dat veel van de aangevoerde studies zijn uitgevoerd op volwassenen die stotteren. Zoals aangegeven door Max \& Daliri (2018) worden verschillen tussen groepen minder consistent gevonden tussen stotterende kinderen en niet-stotterende kinderen ( $\mathrm{p}$. 51-52). Aangezien de geciteerde studies met betrekking tot motorische leereffecten (e.g., Smits-Bandstra \& De Nil, 2013; Smits-Bandstra, De Nil \& Rochon, 2006) ook op volwassenen zijn uitgevoerd, roept het de vraag op of, en zo ja op welke specifieke punten, ze zouden overeenkomen met het (senso)motorisch leren bij kinderen die stotteren. Interessant in deze context is dat wat betreft het specifiek auditieve-motorisch leren studies bij volwassen hebben aangetoond dat stotterende personen hierin beperkter zijn (e.g., Sengupta, Shah, Gore, Loucks, \& Nasir, 2016), maar dat er bij kinderen (vooralsnog) geen verschil is aangetoond (Daliri, Wieland, Cai, Guenther \& Chang, 2018); in deze laatste studie werd er door de auteurs geconcludeerd dat de gevonden verschillen in volwassen die stotteren waarschijnlijk gevolgen of compenserend mechanismen betreffen. Enkele gedragsstudies bij jonge kinderen hebben groepsverschillen aangetoond in spraak-motorische vaardigheid (Smith, Goffman, Sasisekaran \& Weber-Fox, 2012; Usler, Smith \& Weber, 2017; Walsh, Mettel \& Smith, 2015), hetgeen ook aansluit bij gevonden neurologische verschillen tussen stotterende en vloeiend sprekende kinderen (Chang \& Zhu, 2013; Chang, Zhu, Chow \& Angstadt, 2015). 
Sommige studies laten echter wat betreft (verbaal-)motorische coördinatie een aanzienlijke overlap in resultaat tussen groepen zien (Hilger, Zelaznik \& Smith, 2016; Smith et al., 2012).

Dit laatste sluit aan bij het gegeven dat veel van de uitkomsten van dergelijke onderzoeken gebaseerd zijn op groepsgemiddelden en dat er aanzienlijke individuele verschillen kunnen bestaan. Als concreet voorbeeld hiervan willen we een recent experiment uit ons eigen lab bespreken (van de Vorst, van Vugt \& Gracco, 2018). Hierin werden stotterende en niet-stotterende deelnemers gevraagd mee te tikken met een metronoom waarbij de auditieve terugkoppeling (van het tikken) werd vertraagd. In een van de taakjes was de opdracht om het tikken zodanig aan te passen dat de (vertraagde) auditieve terugkoppeling (zoveel mogelijk) samenkomt met de metronoom. Hoewel de groepsgemiddelden overeenkwamen waren er in beide groepen grote individuele verschillen; vooral opvallend was dat een subgroep van stotterende personen, die tijdens een andere taak aangaf baat te hebben bij vertraagde auditieve terugkoppeling (DAF; delayed auditory feedback) tijdens spraak, beter de timing van hun vingerbewegingen aan de vertraagde auditieve terugkoppeling leek te kunnen aanpassen dan de groep met stotterende personen die aangaf geen baat te hebben bij DAF tijdens spraak, evenals de meeste personen uit de controle groep (zie figuur 1).

Deze resultaten suggereren dat stotterende personen mogelijk te classificeren zijn in subgroepen en een sensomotorisch defect in stotteren mogelijk niet universeel voor stotterende sprekers is. Het belang van individuele verschillen in onderzoek naar auditievemotorische integratie wordt ook nog eens onderstreept in een onderzoek naar de effecten van vertraagde auditieve terugkoppeling bij vloeiende sprekers (Loucks, Chon, Kraft \& Ambrose, 2013). Ook onderzoek naar auditieve verwerking bij stotteren toont aan dat er op dit aspect mogelijk subgroepen zijn (Foundas, Bollich, Corey, Hurley \& Heilman, 2001; Howell, Davis \& Williams, 2006). In de komende paragrafen zal verder worden belicht dat er over rol van sensorische terugkoppeling op motoriek in stotteren nog geen algehele eenduidigheid bestaat.

\section{Computationele modellen en simulaties van stotteren}

Naast interne modellen zijn er ook specifieke neurale netwerk modellen van spraak-motorische controle ontwikkeld die het mogelijk maken om spraakproductie te simuleren. Een van deze modellen is het Directions Into Velocities of Articulators model (DIVA; Guenther, Ghosh \& Tourville, 2006) met het GODIVA model (Gradient Order DIVA; Bohland, Bullock \& Guenther, 2010) als uitbreiding hierop. In figuur 2 is een schematische weergave van het DIVA model afgebeeld, waarbij elk blok een groep neuronen representeert die betrokken zijn bij een specifieke taak in een bepaald hersengebied. Voor het testen van specifieke hypothesen over stotteren zijn bepaalde aspecten van het model gemanipuleerd om zodoende te observeren of, en zo ja, hoe en waar er onvloeiendheden optraden in de gesimuleerde spraak. We zullen hier kort ingaan op twee van deze simulaties. 


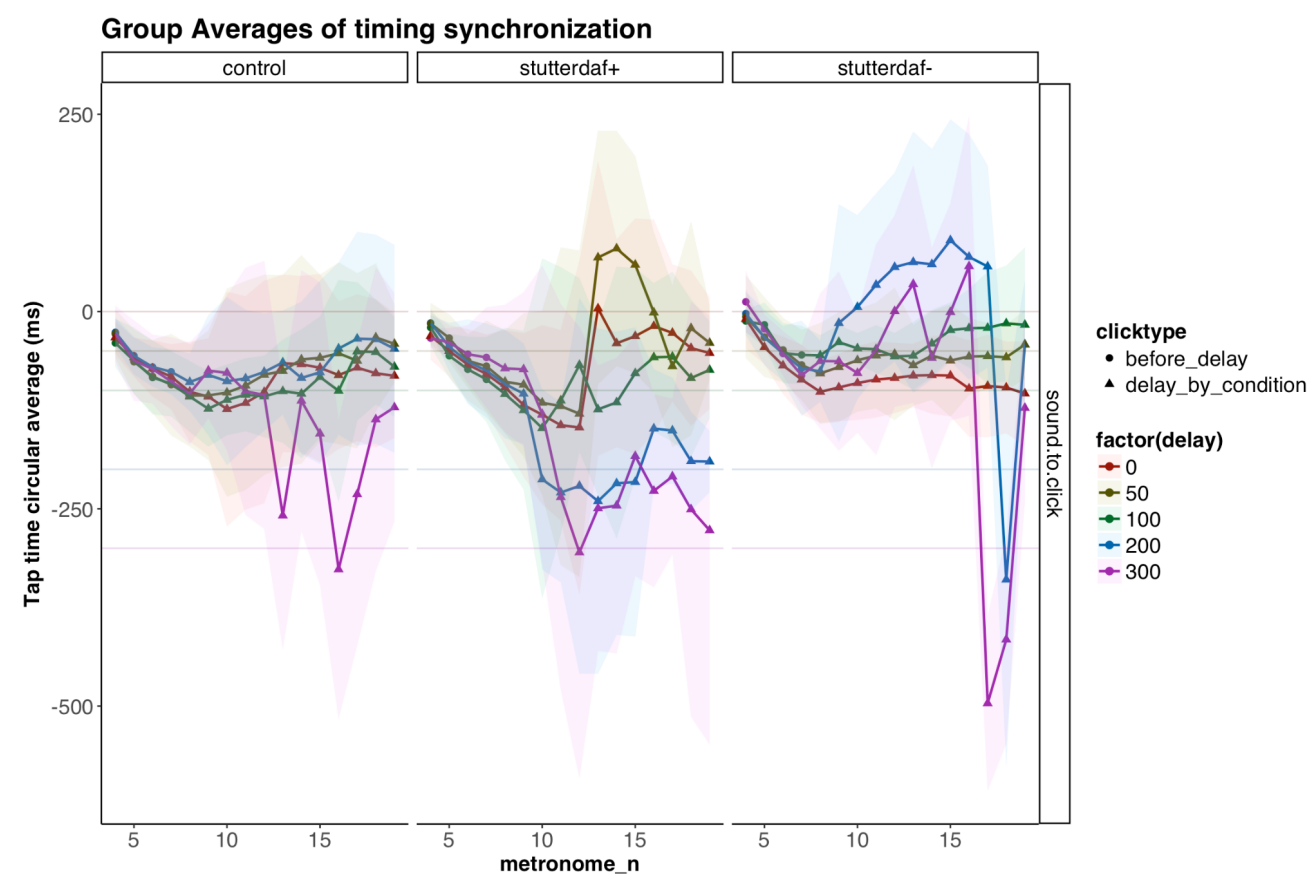

Figuur 1: Preliminaire resultaten uit een poster (van de Vorst, van Vugt \& Gracco, 2018) waarin de compenserende motorische actie als gevolg van vertraagde auditieve terugkoppeling werd vergeleken tussen drie groepen: vloeiende sprekers (control), stotterende sprekers die (in een andere taak) aangaven baat te hebben bij DAF tijdens het spreken (stutterdaf + ) en stotterende sprekers die aangaven geen baat te hebben bij DAF tijdens het spreken (stutterdaf-). De taak was om met vingertikken de vertraagde auditieve terugkoppeling te synchroniseren met de metronoom. De verschillende gekleurde lijnen verwijzen naar de vertragingen in auditieve terugkoppeling. Een 'correcte' uitvoering impliceert dat de negatieve asynchronie in vingertikken (y-as) overeenkomt met de specifieke vertraging. De stutterdaf+ groep slaagde hier relatief het meest in, al was deze statistisch gezien niet significant (non-significante trend, $\mathrm{p}=0.11$ ).

\section{Overmatig vertrouwen op auditieve terugkoppeling}

Volgens Civier et al. (2010) is stotteren mogelijk te wijten is aan een overmatig vertrouwen op auditieve terugkoppeling (zie ook Max et al., 2004). De oorzaak hiervan zou liggen in een verzwakt feedforward (voorwaarts) systeem (zie paars gekleurd blok in figuur 2). Hierdoor treedt een vertraging op in het uitzenden van de motorische commando's zodat er een grotere afhankelijkheid van de daadwerkelijke (vertraagde) terugkoppeling ontstaat, met als gevolg een hogere frequentie van fouten. Deze 'accumulatie van fouten' zouden uiteindelijk tot motorische 'resets' leiden, ofwel herhalingen van lettergrepen (of woorden).

In een reeks van simulaties is zodoende aangetoond dat een bias voor feedback controle kan resulteren in een hogere frequentie van fouten in de vloeiende spraak (Civier et al., 2010). Dit bleek vooral het geval wanneer er sprake is van snelle transities van formanten, aange- 


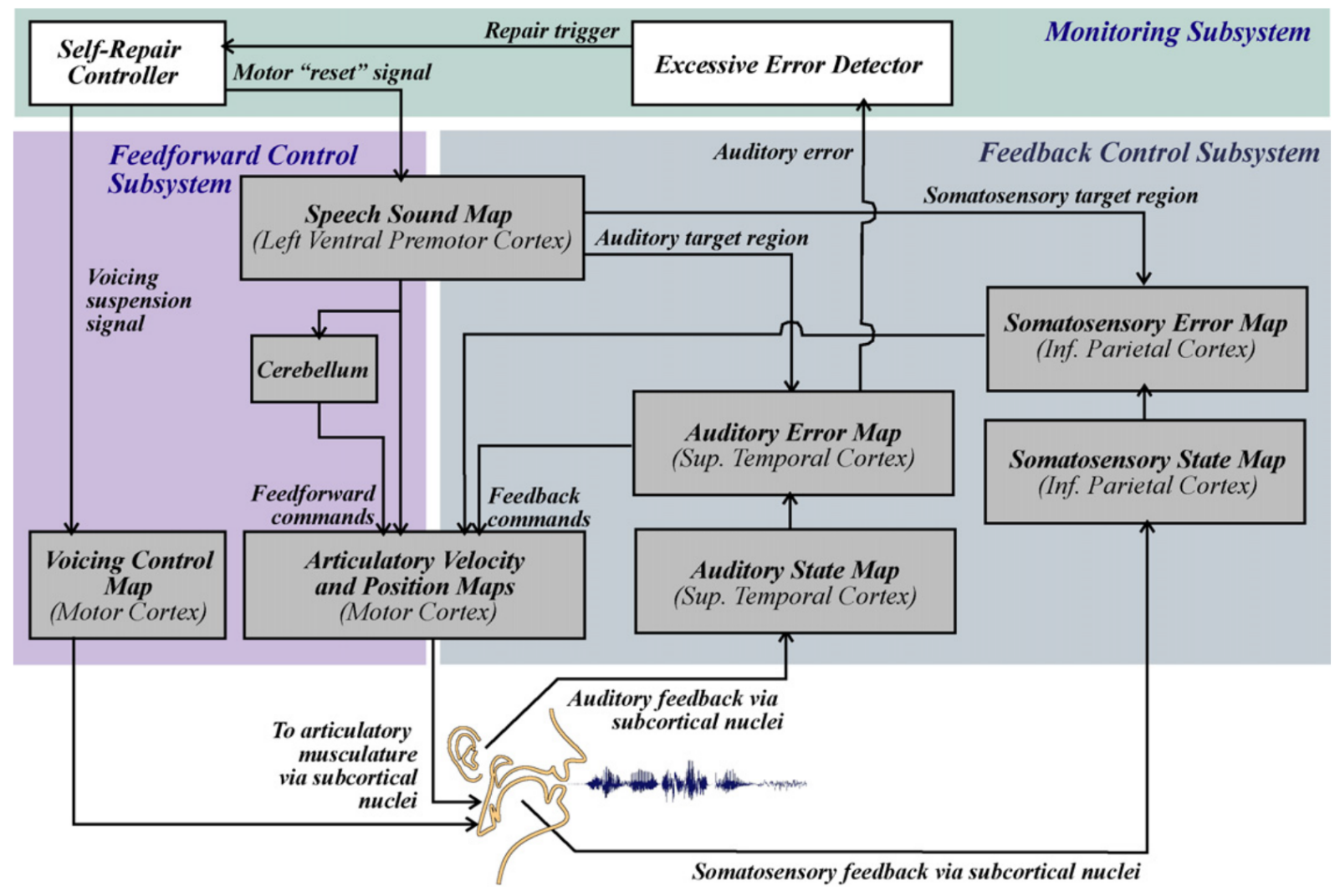

Figuur 2: Schema van het DIVA model (Civier, Tasko \& Guenther, 2010, p. 249). De donkergrijze blokken verwijzen naar de groep neuronen die betrokken zijn bij een specifieke taak in een bepaalde anatomische locatie (bij de witte blokken is deze locatie nog niet bekend). Pijlen verwijzen naar synaptische verbindingen die informatie van de ene naar de andere locatie overdragen. Het model bevat drie subsystemen: het feedforward (voorwaarts) controle subsysteem, het feedback (terugkoppeling) controle subsysteem en het monitoring subsysteem.

zien deze in een kortere tijd gerealiseerd dienen te worden (ongeveer $10 \mathrm{~ms}$ ) dan de tijd die nodig is voor verwerking van auditieve terugkoppeling (ongeveer $60 \mathrm{~ms}$ ). Eveneens liet het model zien dat een teveel aan sensomotorische fouten kan leiden tot het 'resetten' (herhalen) van lettergrepen. Tot slot werd ook onderzocht wat de invloed van vloeiendheidsbevorderende condities is op de gesimuleerde output. De resultaten lieten zien dat vertraagde spraak zorgden voor minder 'fouten' en gemaskeerde ruis minder correcties tot gevolg had. Dit zou mede kunnen verklaren waarom stotterende personen minder stotteren wanneer ze vertraagd spreken of spreken met behulp van vloeiendheidsbevorderende apparaten (e.g., SpeechEasy, die de auditieve terugkoppeling vertraagt). 


\section{Uitgebreide GODIVA model}

Het uitgebreide GODIVA werd gebruikt om verstoringen in specifiek twee verschillende functionele breincircuits, die tot stotterende onvloeiendheden zouden kunnen leiden, te testen: één betreft een verzwakking van de witte stof die de linker basale ganglia en de ventrale premotorische cortex verbinden (een belangrijk circuit voor spraakproductie) en de ander een verhoogd dopeminegehalte eveneens in de basale ganglia (Civier, Bullock, Max \& Guenther, 2013). De specifieke hypothesen waren dat het eerste kan leiden tot een verstoring in het beëindigen (inhiberen) van een voorafgaande lettergreep en het tweede tot een verstoring in het selecteren van de juiste aankomende lettergreep. Beide mechanismen zouden zorgen voor een abnormaal langzame initiatie van het aankomende spraaksegment, dat in combinatie met de reactie van de spreker op de onvloeiendheid de stottersymptomen (herhalingen, verlengingen en blokkades) tot gevolg heeft.

De vloeiendheid van de spraakoutput werd vervolgens getest via een 'neurologisch verstoorde' computer simulatie waarbij de opeenvolging van de lettergrepen /go/-/di/-/va/ werd gebruikt. De resultaten lieten zien dat in beide gevallen (hypothesen) er stotterende onvloeiendheden in de akoestische output werden waargenomen, echter wel op verschillende loci: de verhoogde dopamine in de basale ganglia liet voornamelijk onvloeiendheden zien bij de aanvang van het eerste segment, terwijl de abnormaliteit in de witte stof tussen de ventrale premotorische cortex en linker basale ganglia slechts stotteren in het midden of eind van het woord kon aantonen. Aangezien stotteren vaak voorkomt aan het begin van een zin en de eerste lettergreep van het woord (Hubbard, 1998) lijkt hiermee de tweede hypothese - een verhoogd dopaminegehalte in de basale ganglia dat kan leiden tot problemen in het selecteren van de juiste aankomende lettergreep - het meest aan te sluiten bij wat we weten over het optreden van de loci van stotteren.

\section{Experimenteel bewijs}

Het directe bewijs voor de plausibiliteit van deze twee modellen komt grotendeels voort uit de resultaten van de specifieke simulaties, aangezien het ingewikkeld is om deze modellen direct uit te testen op proefpersonen. Er is desalniettemin voldoende indirect bewijs dat dergelijke mechanismen bij personen die stotteren een rol kunnen spelen in de (ontwikkeling van) onvloeiende spraak. Zo worden bijvoorbeeld zowel in de overmatig vertrouwen op auditieve feedback-hypothese en het uitgebreide GODIVA model de basale ganglia als neurologische substraten geïmpliceerd. Hersenscans bij stotterende personen hebben zowel verschillen laten zien in de structuur en functie van de basale ganglia als ook in de verbindingen tussen corticale en subcorticale gebieden (Chang \& Zhu, 2013; Lu et al., 2013; Watkins, Smith, Davis \& Howell, 2008). Ook een verhoogd dopaminegehalte in de basale ganglia is aangetoond (Wu et al., 1997). Interessant in dit verband is het toenemende bewijs dat farmacologische studies naar stotteren hebben uitgewezen dat dopamine antagonisten (medicatie die het dopamineniveau afremt) een gunstige invloed blijken te hebben op de stotterfrequentie (Maguire et al., 2004; Stager et al., 2005). Verder is het idee van een verzwakte feedforward projectie ook zeer compatibel met hersenstudies die abnormaliteiten 
in de planning van spraak hebben laten zien (Biermann-Ruben, Salmelin \& Schnitzler, 2005; Chang, Kenney, Loucks \& Ludlow, 2009; Mersov, Jobst, Cheyne \& De Nil, 2016).

Het lijkt dus aannemelijk dat bij stotteren de voorwaartse projectie mogelijk problematisch verloopt. Of als gevolg daarvan een bias voor overmatig vertrouwen op auditieve terugkoppeling noodzakelijk leidt tot interrupties in de vloeiende spraak is nog niet geheel duidelijk. In een studie uitgevoerd door Namasivayam, van Lieshout, Mcllroy \& De Nil (2009) werd specifiek de hypothese opgeworpen of personen die stotteren meer afhankelijk zijn van sensorische terugkoppeling; in dat geval zou volgens de auteurs de motorische coördinatie meer variabel moeten zijn bij sensorische perturbaties. De resultaten lieten echter zien dat bij personen die stotteren geen sprake was van een toename in motorische variabiliteit tijdens de verschillende perturbaties. Het idee van een overmatig vertrouwen op auditieve terugkoppeling lijkt ook in tegenspraak met studies die een verzwakte motorische compensatie laten zien na onverwachte perturbaties in auditieve terugkoppeling (e.g., Cai et al., 2012) en hersenstudies die een algemeen verzwakte auditieve activiteit tonen in stotterende personen (Braun et al., 1997; Chang et al., 2009).

Hoewel sensorische terugkoppeling essentieel is voor de ontwikkeling van (vloeiende) spraak is het mogelijk dat het stotteren bij sommigen niet in direct verband staat met sensorische factoren (bijvoorbeeld auditieve terugkoppeling). Een andere mogelijkheid is dat overmatig vertrouwen op sensorische terugkoppeling een strategie weerspiegelt die vloeienheidsbevorderend kan werken (Namasivayam \& van Lieshout, 2011). Zoals eerder beschreven is het niet uitgesloten dat er wat betreft sensorische terugkoppeling subgroepen kunnen bestaan in personen die stotteren. Meer onderzoek zal hier in de toekomst wellicht meer helderheid over verschaffen.

\section{Speech motor skill (SMS) theorie}

Een belangrijk verschil met de voorafgaande spraak-motorische modellen en de speech motor skill (SMS) hypothese is dat laatstgenoemde theorie stelt dat stotteren niet noodzakelijk een spraak-motorische stoornis betreft. In plaats van een 'defect' wordt het spraakmotorisch systeem van stotterende personen gekarakteriseerd als 'beperkt vaardig' en niet stabiel genoeg om de cognitieve, taalkundige, emotionele en motorische aspecten betrokken bij spraak te implementeren. Er wordt gesteld dat stotterende personen spraak-motorisch 'onhandig' zijn, zonder dat er noodzakelijk een specifieke pathologie of ander biochemisch, anatomisch of sensorisch defect aan ten grondslag ligt (van Lieshout et al., 2004, p. 313). Personen die stotteren zouden zich vervolgens bevinden aan het lagere eind van het spectrum wat betreft spraak-motorische controle. Motorische vaardigheid wordt gedefinieerd als een vaardigheid om bewegingen te verkrijgen die nodig zijn voor het efficiënt uitvoeren van een taak met behulp van oefening en om deze (bewegingen) in een georganiseerde, quasi-automatische, energie-effectieve en doelmatige manier uit te kunnen voeren (Namasivayam \& van Lieshout, 2011, p. 477). Beperkte motorische vaardigheden worden onder andere gekenmerkt door bijvoorbeeld veelvuldige fouten of meer variabiliteit in de bewegingen, langzamere uitvoering en afhankelijkheid van sensorische terugkoppeling, eveneens als verminderde automatisatie en onvermogen om een grote vaardigheid te bereiken 
ondanks oefening (Namasivayam \& van Lieshout, 2011, p. 478).

\section{Experimenteel bewijs}

Er lijkt binnen de wetenschappelijke vakliteratuur weinig discussie te zijn dat stotterende personen gemiddeld genomen minder presteren op het gebied van (spraak)motorische vaardigheden. We hebben hierboven enkele gedrags- en hersenstudies genoemd die verschillen laten zien in de planning en executie van motorische handelingen bij stotterende personen, hetgeen mogelijk een probleem met feedforward (voorwaartse) projectie weerspiegelt. Voor een uitgebreidere bespreking van het bewijs voor een verminderde spraakmotoriek verwijzen we naar de artikelen van Lieshout et al. (2004) en Namasivayam \& van Lieshout (2011).

De vraag die echter opgeworpen kan worden is in hoeverre het idee van stotteren als beperkte motorische vaardigheid een inclusieve verklaring biedt voor de verschijnselen die stotteren direct kunnen verminderen en verergeren. In van Lieshout et al. (2004) en Namasivayam \& van Lieshout (2011) worden een aantal van deze vloeiendheidsbevorderende en vloeiendheidsbelemmerende condities besproken. Het behoeft geen discussie dat een manipulatie in de complexiteit van taal en/of motorische processen effect kan hebben op de vloeiendheid; zo lokken grammaticaal complexere zinnen eerder stotteren uit en verbetert de vloeiendheid bij gebruik van een simpelere motorische strategie (e.g., vertraagd spreken).

Dit kan echter niet verklaren waarom factoren die het motorische systeem zouden moeten stabiliseren in bepaalde situaties toch tot (ernstig) stotteren kunnen leiden. Het is bijvoorbeeld niet noodzakelijk dat veelvuldige oefening van een bepaald woord of een zin automatisch leidt tot minder stotteren. Zo wordt doorgaans gestotterd bij het verbaliseren van een inhoudelijke relevante boodschap (bijvoorbeeld de eigen naam), ondanks dat hier veel op geoefend kan zijn en hier geen sprake hoeft te zijn van een (relatief) complexe motorische of taalkundige context. Daarnaast kunnen er grote verschillen zijn afhankelijk van de persoon tegen wie men spreekt; zo komt stotteren minder voor wanneer men spreekt tegen minderjarigen, dieren of wanneer men alleen is (Andrews, Howie, Dozsa \& Guitar, 1982). Ook wordt het stotteren veelal uitgelokt door herinneringen aan bepaalde (spreek)situaties of zelfs specifieke letters en woorden. Door Lu \& Howell (2017) worden angst en zogenaamde 'intrusieve herinneringen' als een van de belangrijkste aan stotteren gerelateerde veranderingen genoemd tijdens adolescentie.

Hieruit blijkt dat met name de psychosociale context, eerder opgedane ervaringen en omgeving belangrijke modulerende factoren kunnen zijn. Hoewel er eensgezindheid is dat deze aspecten niet het stotteren veroorzaken, kunnen deze mogelijk het stotteren wel in stand houden en/of verergeren. Een theorie die het gehele fenomeen stotteren tracht te beschrijven zou wellicht een verklaring moeten kunnen geven voor het contextueel gebonden variabele karakter van stotteren. 


\section{Alternatieve benadering tegenover spraak-motorische model- len}

Hoewel nog onbekend is in hoeverre spraak-motorische factoren het herstel of persisteren van stotteren kunnen voorspellen, blijkt uit de bespreking van de voorafgaande modellen dat het aannemelijk is dat een (spraak-)motorische aanlegfactor meespeelt in de ontwikkeling van het stotteren. Zoals hierboven besproken lijkt stotteren echter ook een contextuele variabele stoornis te zijn, die wellicht niet altijd volledig vanuit taalkundige en (senso)motorische factoren verklaard kan worden. Hoewel we nogmaals willen benadrukken dat uitlokkende factoren zoals stress, nervositeit, angst en traumatische ervaringen doorgaans geen oorzaak zijn van stotteren, kunnen ze desalniettemin op den duur bij adolescenten en volwassenen mogelijk wel een kern van het probleem vormen. Ze kunnen er toe leiden dat er meer negatieve aandacht ontstaat voor het spreken en strategieën worden ontwikkeld om het stotteren te vermijden, factoren die in zogenaamde cognitieve-psycholinguïstische modellen (e.g., vicieuze cirkel hypothese; Vasiç \& Wijnen, 2005) centraal staan. Wellicht dat in de aanleg van stotteren ook cognitieve en persoonlijkheidsfactoren een rol kunnen spelen. Een recent nieuw model voor stotteren, de speech and monitoring interaction hypothese (SAMI; Arenas, 2017) incorporeert zowel persoonlijkheidsfactoren en cognitieve processen (monitoring) en integreert ze met spraak-motorische processen. We willen dit model hier in enig detail toelichten aangezien het een mogelijk antwoord biedt op de vraag hoe en waarom het stotteren contextueel variabel is.

\section{SAMI-model: monitoring}

In het SAMI-model wordt gesteld dat een interactie tussen spraakproductie- en monitoringsfactoren kan verklaren waarom stotteren van moment tot moment kan verschillen. Het bewijs en de plausibiliteit voor een spraak-motorische component is hiervoor besproken en zullen we daarom niet herhalen. In SAMI wordt echter ook een centrale rol toegekend aan het monitoringssysteem, waar we hierbij nader op in willen gaan.

De belangrijkste taak van het monitoringssysteem (een soort van fout-detectie systeem) is het verzamelen van informatie omwille van het optimaliseren van bijvoorbeeld motorische of cognitieve taken (Botvinick, 2007). Het monitoringssysteem reguleert onder andere aandacht en kan bijvoorbeeld een motorische actie bijstellen door deze te inhiberen (tegenhouden), zodat er bijvoorbeeld meer tijd is om een fout(dreiging) te herstellen (MarcoPallarés et al., 2008).

Belangrijk is dat het monitoringssysteem multi-dimensioneel en contextueel variabel is. Zo kan bijvoorbeeld afhankelijk van de situatie het duidelijk overbrengen van de woorden (articulatie) prevaleren of de gepastheid van de inhoudelijke boodschap; iemand die stottert zal zich wellicht concentreren op het niet-stotterend spreken. In alle gevallen is het monitoringssysteem actief, echter verschilt de focus. Afhankelijk van externe factoren en het temperament van de persoon kunnen bepaalde aspecten in ofwel meer dan wel mindere mate gemonitord worden. Het monitoringssysteem bepaalt vervolgens in hoeverre de 
geproduceerde output (spraak) overeenkomt met de gestelde doelstellingen; wordt de grens van 'acceptabele output' overschreden, dan vindt er een (zelf)correctie plaats.

In SAMI wordt verondersteld dat een teveel aan monitoring een nadelig effect kan hebben op de vloeiendheid doordat het de motorische commando's afremt. Hoewel er overlap is tussen auditieve feedback monitoring in spraak-motorische modellen en monitoring in SAMI, verschilt monitoring in SAMI doordat het zich niet slechts beperkt tot het spraakmechanisme, maar ook het cognitief-psychosociale domein bevat; een foutdreiging kan zodoende bijvoorbeeld ook een angst voor een bepaalde sociale situatie betreffen of een herinnering aan een eerder opgedane (in dit verband aan het stotteren gerelateerde) ervaring. In deze gevallen kan het monitoringssysteem getriggerd worden door psychosociale cues, hetgeen vervolgens het spraak-motorische systeem afremt met mogelijk stotteren als gevolg (zie ook sectie Spraakproductie-monitoring interactie over spraak-monitoring interactie).

\section{Trait en state factoren}

In SAMI worden beide componenten, spraakproductie en monitoring, beïnvloed door trait en state factoren (zie figuur 3). Trait factoren zijn relatief langdurig, stabiel en worden doorgaans weinig of niet beïnvloed door context; voorbeelden van spraakproductie gerelateerde trait factoren zijn taalvaardigheid en verbaal-motorische vaardigheden. Een consistente gevonden neurale trait factor wat de betreft de spraakproductie component in stotteren betreft onder-activiteit in het brein in spraak-motorische gebieden in de linkerhelft (Belyk et al., 2017; Conolly et al., 2018). Er zijn mogelijk ook andere neurale trait spraakproductiefactoren, zoals verminderde activatie in hersengebieden betrokken bij auditieve verwerking en overactiviteit in motorische gebieden in de rechterhelft (Belyk et al., 2017).

State factoren daarentegen zijn wél contextgevoelig en van korte duur. Voorbeelden van spraak/taalproductie gerelateerde state factoren in stotteren zijn spreeksnelheid en linguïstische context. Een combinatie van negatieve bias met betrekking tot trait en state factoren binnen het spraakproductiesysteem kunnen ervoor zorgen dat het bijvoorbeeld langer duurt voordat het correcte linguïstisch-motorische plan wordt uitgevoerd, hetgeen kan resulteren in een 'vertraging' in het spraakproductiesysteem, met mogelijk onvloeiendheid of stotteren als gevolg. Zo kan bijvoorbeeld de spreeksnelheid of een bepaalde linguïstische context (state factoren) ervoor zorgen dat iemand met een relatief minder goed ontwikkeld spraak/taalproductiesysteem (trait factor) in deze specifieke context onvloeiend of stotterend spreekt.

Hetzelfde principe geldt voor het monitoringssysteem, waarbij zowel trait en state factoren het uiteindelijke spraak-motorische proces kunnen inhiberen (tegenhouden) met eveneens onvloeiendheid (stotteren) als gevolg. Neurologisch wordt het monitoringssysteem met name toegeschreven aan de Anterior Cingulate Cortex (ACC; Luu, Collins \& Tucker, 2000), maar ook delen van de SMA en de subthalamic nucleus (STN) kunnen betrokken zijn (Danielmeier et al., 2011). Studies hebben trait factoren met betrekking tot monitoring, zoals remmingen in gedrag en risico-mijding, geassocieerd met een verandering in neurale gebieden van het monitoringssysteem (Rudorf, Preuschoff \& Weber, 2012). Een verhoogde activiteit in de ACC wordt ook aangetroffen bij diverse state factoren, zoals emotionele prik- 


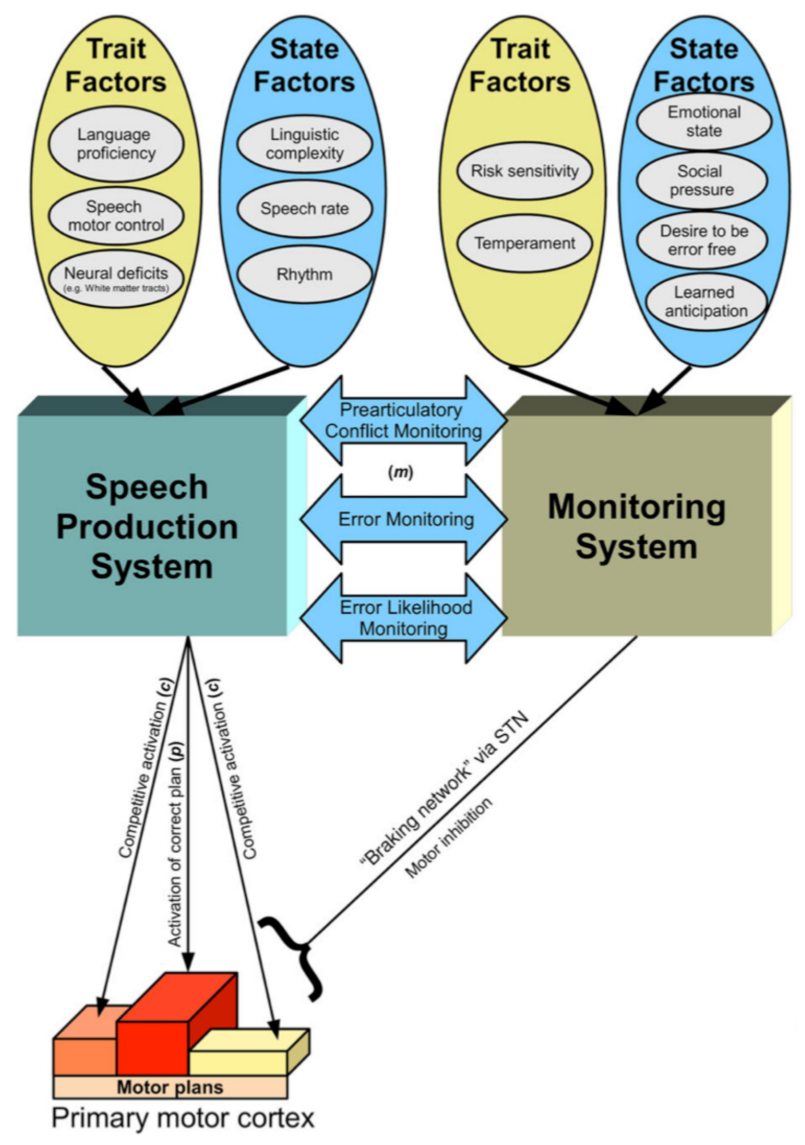

Figuur 3: Schematisch model van SAMI (aangepast van Arenas, 2017)

keling, verhoogde concentratie of aandacht op accuratesse, anticipatie op mogelijke 'fouten' en sociale druk (Brown \& Braver, 2005; Cavanagh \& Allen, 2008). Alcohol en dopamine antagonisten laten daarentegen een verminderde activiteit in dit breingebied zien (Holroyd \& Yeung, 2003; Ridderinkhof et al., 2002). Interessant is dat de eerstgenoemde state factoren allen het stotteren meestal verergeren, terwijl laatstgenoemden het stotteren doorgaans verminderen.

Zoals eerder gesteld kan een teveel aan monitoring (activiteit in ACC) het motorische proces dermate inhiberen zodat de vloeiendheid mogelijk wordt aangetast. Expliciet bewijs dat monitoring en een abnormale activiteit in de ACC een rol kan spelen bij stotteren blijkt uit studies waarbij stotterende personen een verhoogde activiteit in de ACC lieten zien tijdens het lezen, 'scannen' voor woorden en het anticiperen van stotteren (De Nil \& Kroll, 2001; Kroll, De Nil \& Houle 1997). Hersenstudies die specifiek getracht hebben trait en state factoren bij stotterende personen in kaart te brengen laten tot op heden slechts in beperkte mate betrokkenheid van de cingulate cortex zien (Belyk et al., 2017; Conolly et al., 2018). Dit kan mogelijk verklaard worden doordat deze gebieden pas (over-)geactiveerd worden wanneer er zich een concrete, mogelijk extern getriggerde, anticipatie of dreiging van stot- 
teren voordoet, hetgeen in de meeste hersenstudies vanwege de artificiële, soms zelfs vloeiendheidsbevorderende setting, niet het geval is. Dit laatste onderstreept het belang van het integreren, waar mogelijk, van hersenonderzoek in een sociale interactieve setting.

\section{Spraakproductie-monitoring interactie}

In het SAMI-model wordt voorgesteld hoe een suboptimaal functionerend monitoringssysteem het spraakproductiesysteem kan beïnvloeden. Zo kan er een conflict plaatsvinden tussen het monitoring en spraakproductiesysteem wanneer er voorafgaand aan spraak bijvoorbeeld een verkeerde articulatie-code wordt gepland of een verkeerde fonologische eenheid wordt geactiveerd (prearticulatory conflict monitoring). In deze gevallen geeft het monitoringssystem een (te sterk) signaal af naar de spraak/taal planning- en productiesystemen om correcties aan te brengen. Eveneens kunnen er bij het evalueren van de discrepantie tussen de geproduceerde en de geplande spraak een teveel aan 'foutmeldingen' optreden (error monitoring). Dit remt het motorisch systeem af en kan mogelijk leiden tot onvloeiendheden of stotteren. Tenslotte kunnen monitoring- en spraakproductiesystemen met elkaar interfereren door middel van het anticiperen van onvloeiendheid of stotteren (error-likelihood monitoring). Aangezien onvloeiendheid of stotteren doorgaans niet de gewenste spraakvorm is, wordt het monitoringssystem al geactiveerd zodra er een mogelijke onvloeiendheid wordt geanticipeerd, zodat de motorische respons wordt vertraagd of tegengehouden. Wanneer een persoon die stottert bijvoorbeeld eens in een bepaalde situatie heeft gestotterd kan het monitoringssysteem worden geactiveerd wanneer eenzelfde situatie zich opnieuw voordoet. De anticipatie activeert zo het monitoringssysteem waardoor de spraakmotoriek (nog) meer wordt geremd en het daadwerkelijke stotteren moeilijker tegen te houden is. Deze vorm van monitoring sluit aan bij de anticiperende-vechthypothese (Anticipatory Struggle Hypothesis; Bloodstein, 1975) en Wendell Johnson's uitspraak dat 'stotteren datgene is wat je doet om niet te stotteren' (Johnson, 1972).

De eerste twee varianten komen sterk overeen met spraak-motorische modellen zoals hiervoor besproken. Bij de laatste variant (error-likelihood monitoring) is een defect of beperkt vaardige spraak-motorische component wellicht niet noodzakelijk; het kan mogelijk verklaren waarom sommige personen die - wellicht door compensatie - een 'normale' spraak-motorische vaardigheid tonen toch (ernstig) kunnen stotteren (zie ook Brocklehurst, Lickley \& Corley, 2013).

\section{Experimenteel bewijs voor afwijkende monitoring in stotteren als aanlegfactor}

Er zijn dus mogelijk diverse manieren waarop het monitoringssysteem kan interfereren met het spraakproductie mechanisme met (stotterende) onvloeiendheden als gevolg. De vraag is echter hoeveel bewijs er is voor een verstoring van het monitoringssysteem in stotteren. Hierbij dient er wellicht gekeken te worden naar de trait en state factoren die het monitoringssysteem kunnen beïnvloeden. Het staat niet ter discussie dat state factoren zoals een bepaalde emotionele toestand of specifieke context het stotteren kunnen uitlokken en ver- 
ergeren, maar is er ook bewijs voor verschillen in trait factoren, zoals temperament, emotionele reactiviteit en aandacht regulatie, tussen stotterende personen en vloeiende sprekers?

In de literatuur lijken er steeds meer aanwijzingen te zijn dat zowel volwassenen als jonge kinderen die stotteren meer moeite kunnen hebben met het reguleren van emoties en aandacht. Zo werd in 2006 een onderzoek gepubliceerd waarbij ouders werd gevraagd naar emotionele reactiviteit en verwerking van hun kinderen (Karrass et al., 2006). Uit de resultaten bleek dat de kinderen die stotterden een opmerkelijk sterkere reactiviteit vertoonden dan de kinderen die niet stotterden. Dezelfde soort bevindingen, ook in relatie met onvloeiendheid van het kind tijdens emotionele stressvolle situaties, werden bevestigd door verschillende onderzoeken nadien (e.g., Ambrose et al., 2015; Choi et al., 2013). Opvallend is ook het groeiende bewijs voor algemene defecten in het reguleren van aandacht en 'hyperactiviteit' bij kinderen die blijven stotteren (Eggers, De Nil \& Van den Bergh, 2013; JanssonVerkaselo et al., 2012). Aan de hand van deze gegevens is het niet verwonderlijk dat een hoog percentage (58\%) kinderen die stotteren symptomen vertoont die lijken op die van kinderen met ADHD (Donaher \& Richels, 2012). Het gegeven dat kinderen die stotteren (met name jongens) hypervigilant lijken te zijn (Anderson, Pellowski, Conture \& Kelly, 2003; Clark et al., 2015 ) is overeenkomstig met een verstoring in monitoring.

Niet onbelangrijk om te benoemen in dit verband is een zeer recente en omvangrijke hersenstudie naar 84 jonge kinderen die de gedachtegang van bredere en mogelijk niet-spraak gerelateerde oorzaken van stotteren bevestigt (Chang et al., 2017). In deze studie werd met behulp van fMRI de connectiviteit tussen neurale netwerken van het brein geanalyseerd tijdens rusttoestand. Uit de resultaten bleek dat kinderen die stotteren abnormale connectiviteit vertoonden in het zogenaamde 'default mode netwerk' (dat onder andere de Posterior Cingulate Cortex bevat, een gebied dat grenst aan de ACC), hetgeen actief is wanneer een persoon rust of (mogelijk planmatig) nadenkt. Een interessante bevinding was dat de hoeveelheid neurale verbindingen binnen dit gebied en met andere gebieden die betrokken zijn bij aandacht en executieve functies konden voorspellen of een kind zou blijven stotteren of herstellen van stotteren. Er werden ook verschillen aangetoond in verbindingen met breingebieden die betrokken zijn bij spraakmotoriek (somatomotor circuit); deze waren echter zowel aanwezig in de kinderen die bleven stotteren als in de kinderen die herstelden van stotteren. Een conclusie van deze studie was dat mogelijk ook breingebieden en circuits die slechts indirect gerelateerd zijn aan spraak (executieve functies, emotie, etc.) een essentiële rol kunnen spelen in de ontwikkeling van stotteren.

\section{Besluit: implicaties voor de klinische praktijk}

In dit artikel hebben we aan de hand van het bespreken van meerdere spraak-motorische modellen proberen te laten zien dat een spraak-motorische aanleg voor stotteren ogenschijnlijk breder moet worden gezocht dan een veelvuldig door het Nederlands logopedische veld gestelde 'timingstoornis'. We hebben geprobeerd te belichten dat spraak-motorische modellen ook onderling verschillende hypothesen en voorspellingen doen over de aard van stotteren. Zo is er bijvoorbeeld geen eenduidigheid of het gaat om een specifieke moto- 
rische stoornis of slechts een beperkte vaardigheid. Ook over de rol van sensorische (bijvoorbeeld auditieve) terugkoppeling worden verschillende voorspellingen gedaan. Daarnaast hebben we getracht in kaart te brengen dat spraak-motorische benaderingen niet altijd alle verschijnselen van stotteren kunnen verklaren; het is zeer waarschijnlijk dat andere, niet noodzakelijk spraak gerelateerde factoren - zoals temperament, emoties en executieve functies - ook in belangrijke mate de ontwikkeling en contextuele variabiliteit van het stotteren kunnen verklaren. Mogelijk dat er in dit opzicht ook aanleg (trait) en oorzakelijke factoren kunnen zijn. Zodoende menen we dat de door de NVST gedane uitspraak dat een timingstoornis de al dan niet genetisch bepaalde aanleg is voor het stotteren genuanceerd dient te worden. Eveneens menen we dat onderzoeken hebben laten zien dat mogelijk minder goed functionerende breingebieden door middel van (goede) therapie zich (gedeeltelijk) kunnen normaliseren en dat de mogelijke onderliggende stoornis, ook bij volwassenen die stotteren, allerminst statisch hoeft te zijn.

De recente ontwikkelingen in het theoretische veld hebben ook implicaties voor het therapeutisch handelen. Zo hebben veel studies verschillen laten zien tussen stotterende en niet-stotterende personen in dieper gelegen breingebieden zoals de basale ganglia en hun verbindingen met corticale gebieden; mogelijk is er sprake van een verhoogd dopaminegehalte bij personen die stotteren. Farmacologische studies naar stotteren tonen dat dopamineantagonisten bij personen die stotteren effectief zijn in het verminderen van stottersymptomen. We verwachten dat in de nabije toekomst naast gedragstherapie ook medicatie kan worden ingezet om stotteren te behandelen.

Aangezien de literatuur over theorievorming omtrent stotteren een complexe relatie tussen verschillende factoren onderschrijft, denken we dat (gedrags)therapie bij stotteren een gebalanceerde interactie tussen deze factoren zou moeten weerspiegelen. Daarbij gaat het in essentie om het integreren van verbaal-motorische aspecten met cognitief-emotionele en sociale factoren. Specifiek zou gezocht kunnen worden naar een balans tussen enerzijds het verbeteren van verbaal-motorische aspecten en anderzijds het verminderen van een teveel aan (spraak)monitoring. Bij het eerste kunnen wellicht sensorische aspecten worden geïntegreerd, zoals auditieve aandacht en visualisatie, zodat het motorisch systeem extra kan worden ondersteund. Tegelijk kan de druk op het monitoringssysteem worden verlicht met behulp van bijvoorbeeld cognitieve gedragstherapie of, meer recent, Acceptance and Commitment Therapy (Hayes, Strosahl \& Wilson, 1999). Concreet zou in kaart worden gebracht hoe bijvoorbeeld factoren gerelateerd aan temperament en persoonlijkheid in relatie staan met (triggers van) individuele stottermomenten en hoe een spreektechniek specifiek ingebed kan worden in het werken aan psychosociale componenten zodat er sprake is van een geïntegreerde benadering.

Op dit moment weten we niet welke (aspecten van) therapieën voor jongeren en volwassenen in Nederland het meest aanslaan bij individuen die stotteren, aangezien vele stotterprogramma's (nog) niet wetenschappelijk zijn onderzocht of voldoende effectiviteit hebben aangetoond op zowel stotterernst als psychosociale aspecten (Huinck \& Peters, 2004). Een enquête naar tevredenheid of een vergelijkende studie zou daarom zeer wenselijk zijn om hierover meer inzicht te kunnen verkrijgen. 
We hopen dat we in dit artikel hebben kunnen laten zien dat over de oorzaak en ontwikkeling van stotteren in de wetenschap nog geen eensgezindheid is. We verwachten dat toekomstige, waarschijnlijk multifactoriële, modellen deze interactie steeds nauwkeuriger kunnen gaan voorspellen en vervolgens effectief kunnen implementeren in therapie.

\section{Dankwoord}

Het vervaardigen van dit artikel is mede mogelijk gemaakt door NIH (DC-015855) en CIHR subsidies (MOP 137001) aan de tweede auteur.

\section{Referenties}

Ambrose, N. G., Yairi, E., Loucks, T. M., Seery, C. H., \& Throneburg, R. (2015). Relation of motor, linguistic and temperament factors in epidemiologic subtypes of persistent and recovered stuttering: Initial findings. Journal of fluency disorders, 45, 12-26. https://doi.org/10.1016/j.jfludis.2015.10.001

Anderson, J. D., Pellowski, M., Conture, E., \& Kelly, E. (2003). Temperamental characteristics of young children who stutter. Journal of Speech, Language, and Hearing Research, 46. https://doi.org/10.1044/1092-4388(2003/095)

Andrews, G., Howie, P. M., Dozsa, M., \& Guitar, B. E. (1982). Stuttering: pattern characteristics under fluency-inducing conditions. Journal of Speech \& Hearing Research, 25(2), 208-216.

Arenas, R. M. (2017). Conceptualizing and investigating the contextual variability of stuttering: The speech and monitoring interaction (SAMI) framework. Speech, Language and Hearing, 20(1), 15-28. https://doi.org/10.1080/2050571x.2016.1221877

Belyk, M., Kraft, S. J., \& Brown, S. (2017). Stuttering as a trait or a state revisited: motor system involvement in persistent developmental stuttering. European Journal of Neuroscience, 45(4), 622-624. https://doi.org/10.1111/ejn.13512

Biermann-Ruben, K., Salmelin, R., \& Schnitzler, A. (2005). Right rolandic activation during speech perception in stutterers: A MEG study. NeuroImage, 25(3), 793-801. http://doi.org/10.1016/j.neuroimage.2004.11.024

Bloodstein, O. (1975). Stuttering as tension and fragmentation. In J. Eisenson (Ed.), Stuttering: A second symposium (pp. 1âĂŞ96). New York: Harper \& Row.

Bloodstein, O., \& Bernstein Ratner, N. (2008). A handbook on stuttering. New York: Thomson Delmar Learning.

Bohland, J. W., Bullock, D., \& Guenther, F. H. (2010). Neural representations and mechanisms for the performance of simple speech sequences. Journal of cognitive neuroscience, 22(7), 1504-1529. https://doi.org/10.1162/jocn.2009.21306

Botvinick, M. M. (2007). Conflict monitoring and decision making: reconciling two perspectives on anterior cingulate function. Cognitive, Affective, \& Behavioral Neuro- 
science, 7(4), 356-366. https://doi.org/10.3758/cabn.7.4.356

Braun, A. R., Varga, M., Stager, S., Schulz, G., Selbie, S., Maisog, J. M., ... \& Ludlow, C. L. (1997). Altered patterns of cerebral activity during speech and language production in developmental stuttering. An H2 (15) O positron emission tomography study. Brain: a journal of neurology, 120(5), 761-784. https://doi.org/10.1093/brain/120.5.761

Brocklehurst, P. H., Lickley, R. J., \& Corley, M. (2013). Revisiting Bloodstein's anticipatory struggle hypothesis from a psycholinguistic perspective: a variable release threshold hypothesis of stuttering. Journal of Communication Disorders, 46(3), 217-237. https://doi:10.1016/j.jcomdis.2013.04.002

Brown, J. W., \& Braver, T. S. (2005). Learned predictions of error likelihood in the anterior cingulate cortex. Science, 307(5712), 1118-1121. https://doi.org/10.1126/science.1105783

Cai, S., Beal, D. S., Ghosh, S. S., Tiede, M. K., Guenther, F. H., \& Perkell, J. S. (2012). Weak responses to auditory feedback perturbation during articulation in persons who stutter: evidence for abnormal auditory-motor transformation. PloS one, 7(7), e41830. https://doi.org/10.1371/journal.pone.0041830

Cavanagh, J. F., \& Allen, J. J. (2008). Multiple aspects of the stress response under social evaluative threat: An electrophysiological investigation Psychoneuroendocrinology, 33(1), 41-53. https://doi.org/10.1016/j.psyneuen.2007.09.007

Chang, S. E., Angstadt, M., Chow, H. M., Etchell, A. C., Garnett, E. O., Choo, A. L., ... \& Sripada, C. (2017). Anomalous network architecture of the resting brain in children who stutter. Journal of fluency disorders, 55, 46-67. https://doi.org/10.1016/j.jfludis.2017.01.002

Chang, S. E., Kenney, M. K., Loucks, T. M., \& Ludlow, C. L. (2009). Brain activation abnormalities during speech and non-speech in stuttering speakers. NeuroImage, 46(1), 201-212. https://doi.org/10.1016/j.neuroimage.2009.01.066

Chang, S. E., \& Zhu, D. C. (2013). Neural network connectivity differences in children who stutter. Brain, 136(12), 3709-3726.

Chang, S. E., Zhu, D. C., Choo, A. L., \& Angstadt, M. (2015). White matter neuroanatomical differences in young children who stutter. Brain, 138(3), 694-711. https://doi.org/10.1093/brain/awu400

Choi, D., Conture, E. G., Walden, T. A., Lambert, W. E., \& Tumanova, V. (2013). Behavioral inhibition and childhood stuttering. Journal of Fluency Disorders, 38(2), 171-183. https://doi.org/10.1016/j.jfludis.2013.03.001

Civier, O., Bullock, D., Max, L., \& Guenther, F. H. (2013). Computational modeling of stuttering caused by impairments in a basal ganglia thalamo-cortical circuit involved in syllable selection and initiation. Brain and language, 126(3), 263-278. https://doi.org/10.1016/j.bandl.2013.05.016

Civier, O., Tasko, S. M., \& Guenther, F. H. (2010). Overreliance on auditory feedback may lead to sound/syllable repetitions: simulations of stuttering and fluency- inducing conditions with a neural model of speech production. Journal of fluency disorders, 35(3), 246-279. https://doi.org/10.1016/j.jfludis.2010.05.002

Clark, C. E., Conture, E. G., Walden, T. A., \& Lambert, W. E. (2015). Speech-language dissoci- 
ations, distractibility, and childhood stuttering. American Journal of Speech-Language Pathology, 24(3), 480-503. https://doi.org/10.1044/2015_ajslp-14-0198

Connally, E. L., Ward, D., Pliatsikas, C., Finnegan, S., Jenkinson, M., Boyles, R., \& Watkins, K. E. (2018). Separation of trait and state in stuttering. Human brain mapping. https://doi.org/10.1002/hbm.24063

Daliri, A., Wieland, E. A., Cai, S., Guenther, F. H., \& Chang, S. E. (2018). Auditory-motor adaptation is reduced in adults who stutter but not in children who stutter. Developmental Science, 21(2), e12521. https://doi.org/10.1111/desc.12521

Danielmeier, C., Eichele, T., Forstmann, B. U., Tittgemeyer, M., \& Ullsperger, M. (2011). Posterior medial frontal cortex activity predicts post-error adaptations in task-related visual and motor areas. Journal of Neuroscience, 31(5), 1780-1789. https://doi.org/10.1523/jneurosci.4299-10.2011

De Nil, L. F., \&, R. M. (2001). Searching for the neural basis of stuttering treatment outcome: recent neuroimaging studies. Clinical Linguistics \& Phonetics, 15(1-2), 163-168. https://doi.org/10.1080/026992001461505

Donaher, J., \& Richels, C. (2012). Traits of attention deficit/hyperactivity disorder in schoolage children who stutter. Journal of fluency disorders, 37(4), 242-252. https://doi.org/10.1016/j.jfludis.2012.08.002

Etchell, A. C., Johnson, B. W., \& Sowman, P. F. (2014). Behavioral and multimodal neuroimaging evidence for a deficit in brain timing networks in stuttering: a hypothesis and theory. Frontiers in Human Neuroscience, 25(8), 467.

http://dx.doi.org/10.3389/fpsyg.2015.00847

Falk, S., Müller, T., \& Dalla Bella, S. (2015). Non-verbal sensorimotor timing deficits in children and adolescents who stutter. Frontiers in Psychology, 6, 847. http://dx.doi.org/10.3389/fpsyg.2015.00847

Foundas, A. L., Bollich, A. M., Corey, D. M., Hurley, M., \& Heilman, K. M. (2001). Anomalous anatomy of speech-language areas in adults with persistent developmental stuttering. Neurology, 57(2), 207-215. https://doi.org/10.1212/WNL.57.2.207

Giraud, A. L., Neumann, K., Bachoud-Levi, A. C., von Gudenberg, A. W., Euler, H. A., Lanfermann, H., \& Preibisch, C. (2008). Severity of dysfluency correlates with basal ganglia activity in persistent developmental stuttering. Brain and Language, 104(2), 190-199. http://dx.doi.org/10.1016/j.bandl.2007.04.005

Guenther, F. H., Ghosh, S. S., \& Tourville, J. A. (2006). Neural modeling and imaging of the cortical interactions underlying syllable production. Brain and language, 96(3), 280301. https://doi.org/10.1016/j.bandl.2005.06.001

Hayes, S. C., Strosahl, K., \& Wilson, K. G. (1999). Acceptance and commitment therapy: An experiential approach to behavior change. New York: Guildford Press.

Hilger, A. I., Zelaznik, H., \& Smith, A. (2016). Evidence that bimanual motor timing performance is not a significant factor in developmental stuttering. Journal of Speech, Language and Hearing Research, 59(4), 674-685. https://doi.org/10.1044/2016_jslhrs-15-0172

Holroyd, C. B., \& Yeung, N. (2003). Alcohol and error processing. Trends in neurosciences, 26(8), 402-404. https://doi.org/10.1016/s0166-2236(03)00175-9 
Howell, P., \& Au-Yeung, J. (2002). The EXPLAN theory of fluency control and the diagnosis of stuttering. In: Fava, E., (ed). Pathology and therapy of speech disorders. Amsterdam: John Benjamins; p.75-94. https://doi.org/10.1075/cilt.227.08

Howell, P., Davis, S., \& Williams, S. M. (2006). Auditory abilities of speakers who persisted, or recovered, from stuttering. Journal of fluency disorders, 31(4), 257-270. https://doi.org/10.1016/j.jfludis.2006.07.001

Howell, P., \& Lu, C. (2016). Facts and theories about stuttering. In van Lieshout, P., Maassen, B., \& Terband, H. (eds.) Speech Motor Control in Normal and Disordered Speech: Future Developments in Theory and Methodology. (pp. 147-172). ASHA Press: Rockville, MD, USA

Hubbard, C. P. (1998). Stuttering, stressed syllables, and word onsets. Journal of Speech, Language, and Hearing Research, 41(4), 802-808. https://doi.org/10.1044/jslhr.4104.802

Huinck, W.J., \& Peters, H.F.M. (2004). Effectiviteitonderzoek bij stottertherapieën. Een longitudinale observationele studie naar therapeutische effecten van drie verschillende therapievormen. Nijmegen: Nijmegen University Press.

Jansson-Verkasalo, E., Eggers, K., Aro, K., De Nil, L. F., \& Van den Bergh, B. R. (2012, March). Auditory attention shifting in children who stutter. In European Symposium on Fluency Disorders. https://doi.org/10.1044/2017_jslhr-s-16-0096

Jansson-Verkasalo, E., Eggers, K., Järvenpää, A., Suominen, K., Van den Bergh, B., De Nil, L., \& Kujala, T. (2014). Atypical central auditory speech-sound discrimination in children who stutter as indexed by the mismatch negativity. Journal of fluency disorders, 41, 1-11. https://doi.org/10.1016/j.jfludis.2014.07.001

Johnson, W. (1972). Desirable Objectives and Procedures For an Adult Stutterer, in To the Stutterer (Stuttering Foundation of America Publication, No. 9), M. Fraser (ed). 1972, Stuttering Foundation of America. p. 22.

Karrass, J., Walden, T. A., Conture, E. G., Graham, C. G., Arnold, H. S., Hartfield, K. N., \& Schwenk, K. A. (2006). Relation of emotional reactivity and regulation to childhood stuttering. Journal of communication disorders, 39(6), 402-423.

https://doi.org/10.1016/j.jcomdis.2005.12.004

Kikuchi, Y., Okamoto, T., Ogata, K., Hagiwara, K., Umezaki, T., Kenjo, M., ... \& Tobimatsu, S. (2017). Abnormal auditory synchronization in stuttering: a magnetoencephalographic study. Hearing research, 344, 82-89. https://doi.org/10.1016/j.heares.2016.10.027

Kroll, R., De Nil, L., \& Houle, S. (1997). The use of positron emission tomography for the investigation of changes in brain activation patterns following intensive stuttering treatment. Journal of Fluency Disorders, 2(22), 116. https://doi.org/10.1016/s0094-730x(97)89264-9

Loucks, T. M., Chon, H., Kraft, S., \& Ambrose, N. (2013). Individual differences in auditorymotor integration revealed by speech fluency manipulations. The Journal of the Acoustical Society of America, 133(5), 3518-3518. https://doi.org/10.1121/1.4806306

Loucks, T. M., \& De Nil, L. F. (2006). Oral kinesthetic deficit in adults who stutter: a targetaccuracy study. Journal of Motor Behavior, 38, 238-246. 
https://doi.org/10.3200/jmbr.38.3.238-247

Lu, C., Peng, D., Chen, C., Ning, N., Ding, G., Li, K., ... \& Lin, C. (2010). Altered effective connectivity and anomalous anatomy in the basal ganglia-thalamocortical circuit of stuttering speakers. Cortex, 46(1), 49-67. https://doi.org/10.1016/j.cortex.2009.02.017

Luu, P., Collins, P., \& Tucker, D. M. (2000). Mood, personality, and self-monitoring: negative affect and emotionality in relation to frontal lobe mechanisms of error monitoring. Journal of Experimental Psychology: General, 129(1), 43. https://doi.org/10.1037//0096-3445.129.1.43

Maguire, G. A., Yu, B. P., Franklin, D. L., \& Riley, G. D. (2004). Alleviating stuttering with pharmacological interventions. Expert Opinion on Pharmacotherapy, 5(7), 1565-1571. https://doi.org/10.1517/14656566.5.7.1565

Marco-Pallarés, J., Camara, E., Münte, T. F., \& Rodríguez-Fornells, A. (2008). Neural mechanisms underlying adaptive actions after slips. Journal of cognitive neuroscience, 20(9), 1595-1610. https://doi.org/10.1162/jocn.2008.20117

Max, L., \& Daliri, A. (2018). Een selectief overzicht van sensorische integratieproblemen van spraak en niet-spraak bij individuen die stotteren. Stem-, Spraak-en Taalpathologie, 23, 81-97. https://doi.org/10.21827/5c066bfa3711e

Max, L., \& Gracco, V. L. (2005). Coordination of oral and laryngeal movements in the perceptually fluent speech of adults who stutter. Journal of Speech, Language and Hearing Research, 48, 524-542. https://doi.org/10.1044/1092-4388(2005/036)

Max, L., Guenther, F. H., Gracco, V. L., Ghosh, S. S., \& Wallace, M. E. (2004). Unstable or insufficiently activated internal models and feedback-biased motor control as sources of dysfluency: A theoretical model of stuttering. Contemporary Issues in Communication Sciences and Disorders, 31, 105-122.

Mersov, A. M., Jobst, C., Cheyne, D. O., \& De Nil, L. (2016). Sensorimotor oscillations prior to speech onset reflect altered motor networks in adults who stutter. Frontiers in human neuroscience, 10, 443. https://doi.org/doi10.3389/fnhum.2016.00443

Namasivayam, A. K., \& van Lieshout, P. (2011). Speech motor skill and stuttering. Journal of motor behavior, 43(6), 477-489. https://doi.org/10.1080/00222895.2011.628347

Namasivayam, A. K., van Lieshout, P., McIlroy, W. E., \& De Nil, L. (2009). Sensory feedback dependence hypothesis in persons who stutter. Human movement science, 28(6), 688707. https://doi.org/10.1016/j.humov.2009.04.004

Orton, S. T. (1928). A physiological theory of reading disability and stuttering in children. New England Journal of Medicine, 199, 1045-1052. https://doi.org/10.1056/nejm192811221992108

Packman, A., \& Attanasio, J. S. (2017). Theoretical issues in stuttering. Routledge.

Ridderinkhof, K. R., Vlugt, Y., Bramlage, A., Spaan, M., Elton, M., Snel, J., et al. (2002). Alcohol consumption impairs detection of performance errors in mediofrontal cortex. Science, 298, 2209-2211. doi:10.1126/science.1076929

Rudorf, S., Preuschoff, K., \& Weber, B. (2012). Neural correlates of anticipation risk reflect risk preferences. Journal of Neuroscience, 32(47), 16683-16692.

https://doi.org/10.1523/jneurosci.4235-11.2012

Smith, A., Goffman, L., Sasisekaran, J., \& Weber-Fox, C. (2012). Language and motor abil- 
ities of preschool children who stutter: Evidence from behavioral and kinematic indices of nonword repetition performance. Journal offluency disorders, 37(4), 344-358. https://doi.org/10.1016/j.jfludis.2012.06.001

Smits-Bandstra, S., \& De Nil, L. (2009). Speech skill learning of persons who stutter and fluent speakers under single and dual task conditions. Clinical Linguistics \& Phonetics, 23(1), 38-57. https://doi.org/10.1080/02699200802394914

Smits-Bandstra, S., De Nil, L. F., \& Saint-Cyr, J. (2006). Motor sequence learning in adults who stutter. Journal of Fluency Disorders, 31, 116-131.

https://doi.org/10.1080/00222895.2014.961890

Stager, S. V., Calis, K., Grothe, D., Bloch, M., Berensen, N. M., Smith, P. J., et al. (2005). Treatment with medications affecting dopaminergic and serotonergic mechanisms: Effects on fluency and anxiety in persons who stutter. Journal of Fluency Disorders, 30(4), 319-335. https://doi.org/10.1016/j.jfludis.2005.09.004

Tahaei, A. A., Ashayeri, H., Pourbakht, A., \& Kamali, M. (2014). Speech evoked auditory brainstem response in stuttering. Scientifica, 2014. https://doi.org/10.1155/2014/328646

Toyomura, A., Fujii, T., \& Kuriki, S. (2011). Effect of external auditory pacing on the neural activity of stuttering speakers. NeuroImage, 57(4), 1507-1516.

http://dx.doi.org/10.1016/j.neuroimage.2011.05.039

Usler, E., Smith, A., \& Weber, C. (2017). A lag in speech motor coordination during sentence production is associated with stuttering persistence in young children. Journal of Speech, Language, and Hearing Research, 60(1), 51-61. https://doi.org/10.1044/2016_JSLHR-S-15-0367

Vasiç, N., \& Wijnen, F. (2005). Stuttering as a monitoring deficit. In R. J. Hartsuiker, R. Bastiaanse, A. Postma, \& F. Wijnen (Eds.), Phonological encoding and monitoring in normal and pathological speech (pp. 226-247). Hove, United Kingdom: Psychology Press.

Van de Vorst, van Vugt \& Gracco. (2018). Non-verbal sensorimotor integration is altered in a subtype of people who stutter who benefit from delayed auditory feedback during speech. Poster session presented at The Inaugural Joint World Congress for Stuttering and Cluttering, Hiroshima, Japan.

Van de Vorst, R., \& Gracco, V. L. (2017). Atypical non-verbal sensorimotor synchronization in adults who stutter may be modulated by auditory feedback. Journal of Fluency Disorders, 53, 14-25. https://doi.org/10.1016/j.jfludis.2017.05.004

Van Lieshout, P. H. H. M., Hulstijn, W., \& Peters, H. F. M (2004). Searching for the weak link in the speech production chain of people who stutter: A motor skill approach. In B. Maassen, R. Kent, H. F. M. Peters, P. Van Lieshout, \& W. Hulstijn (Eds.), Speech motor control in normal and disordered speech (pp. 313-355). Oxford, England: Oxford University Press.

Van Lieshout, P. H. H. M., Peters, H. F. M., Starkweather, C. W., \& Hulstijn, W. (1993). Physiological differences between stutterers and nonstutterers in perceptually fluent speech: EMG amplitude and duration. Journal of Speech and Hearing Research, 36, 55-63. https://doi.org/10.1044/jshr.3601.55

Van Riper, C. (1982). The nature of stuttering. Prentice Hall. 
Walsh, B., Mettel, K. M., \& Smith, A. (2015). Speech motor planning and execution deficits in early childhood stuttering. Journal of Neurodevelopmental Disorders, 7(1), 27. https://doi.org/10.1186/s11689-015-9123-8

Walsh, B., \& Smith, A. (2013). Oral EMG activation patterns for speech are similar in preschoolers who do and do not stutter. Journal Speech, Language \& Hearing Research, 56, 14411454. https://doi.org/10.1044/1092-4388(2013/12-0177)

Watkins, K. E., Smith, S. M., Davis, S., \& Howell, P. (2008). Structural and functional abnormalities of the motor system in developmental stuttering. Brain, 131(1), 50-59. http://dx.doi.org/10.1093/brain/awm241

Wu, J. C., Maguire, G., Riley, G., Fallon, J., LaCasse, L., Chin, S., ... \& Lottenberg, S. (1995). A positron emission tomography [-1-8F] deoxyglucose study of developmental stuttering. Neuroreport: An International Journal for the Rapid Communication of Research in Neuroscience. https://doi.org/10.1097/00001756-199502000-00024 